\title{
ANALISIS SISTEM PENETAPAN FRANCHISE FEE DAN ROYALTY FEE PADA FRANCHISE BRC
}

\author{
Walid Darmawan \\ STIES Bina Guna Lombok \\ Email: walid-dr@yahoo.com
}

\begin{abstract}
Abstrak: Pada saat ini bisnis franchise atau waralaba di indonesia, semakin menjamur dan banyak diminati oleh masyarakat untuk mencari peluang baru, dari mulai waralaba lokal seperti Ayam bakar Wong Solo, Es Teller 77, Burger Mr.Edam,Alfa Mart, Indomart dan lain-lain. Sampai waralaba mancanegarapun semakin banyak diminati seperti KFC, Mc.Donalds, Hoka-Hoka Bento, Starbuck Coffiee dan lain sebagainya.
\end{abstract}

Kata Kunci: Franchise, Fee, Royalty

\section{Pendahuluan}

Pada tahun 2008 jumlah pangangguran di Indonesia mencapai 9,43 juta orang ${ }^{1}$ hal ini menyebabkan tingkat kemiskinan dan tindak kriminal menjadi meningkat, belum lagi pada tahun 2008 ditambah dengan krisis finansial yang mengakibatkan beberapa perusahaan harus mengurangi jumlah karyawannya karena menurunnya omset penjualan dan naiknya harga bahan-bahan yang harus di impor. Hal ini semakin memperburuk keadaan.

Padahal menurut pendapat salah seorang pakar ekonomi David Mc.Clelland, "negara bisa makmur kalau jumlah enterpreneur (wirausaha) sedikitnya $2 \%$ dari populasi penduduk". ${ }^{2}$ Pada tahun 2007 di negara maju seperti amerika serikat, jumlah wirausahawan mencapai $11,5 \%$ dari total

1 "Jumlah Pengguran di Indonesia 9.43 Juta Orang" diakses pada 05 Januari 2009 dari http://www.tempointeraktif.com

${ }^{2}$ Y.Bayu dan Nadia Maharani "Peringkat Doing Bussiness 2009 Indonesia Turun Kelas, Lebih Mudah Buka Usaha di Mongolia" artikel diakses pada 16 Maret 2009 dari http://www. madani-ri.com 
penduduknya, Singapura memiliki 7,2\% wirausahawan dari total penduduknya. Adapun di Indonesia hanya memiliki wirausahawan 0,18\% atau 400.000 jiwa dari total penduduknya diatas 220 juta jiwa, idealnya memiliki $5 \%$ dari total penduduknya agar bisa lebih maju. ${ }^{3}$

Apabila di Indonesia ada sekitar 4,4 juta jiwa yang menjadi wirausaha maka perekonomian negara bisa menjadi lebih baik. Minimnya jumlah wira usaha di Indonesia, tidak dimanfaatkan secara optimal untuk menambah kesejahteraan dan kemakmuran bangsa. Selama ini kelemahan wirausaha sering terkendala masalah akses jaringan pemasaran dan permodalan.

Pada kenyataannya masalah jaringan pemasaran dan permodalan bukanlah hal utama. Banyak cara untuk menjadi wirausahawan, antara lain mendirikan bisnis sendiri atau membeli sistem bisnis yang sudah jadi. Masing-masing mempunyai kelebihan dan kekurangan. Kelebihan dalam medirikan bisnis sendiri jenis usaha yang akan didirikan dan pengaturan dapat disesuaikan dengan keinginan kita sendiri, sedangkan kekurangannya, sistem bisnis mulai dari nol, pasar belum ada, sehingga banyak yang baru dibangun akhirnya gagal.

Sedangakan membeli sistem bisnis yang sudah jadi mempunyai kelebihan bahwa sistem bisnis sudah tercipta dan siap pakai, si pembeli bisnis tinggal menjalankan saja didalam sistem yang sudah ada itu. Demikian juga pasar sudah ada sehingga tidak akan mengalami kesulitan dalam memasarkan produknya. Kelemahannya adalah pemilik modal tidak akan bebas dalam menentukan usahanya, karena semuanya tergantung kepada pihak yang dibeli bisnisnya.

Sehubungan dengan berwirausaha dengan membeli bisnis yang sudah ada, dikenal istilah franchise yang sudah di-Indonesia-kan menjadi waralaba. franchise atau waralaba merupakan suatu perikatan dimana salah satu pihak diberikan hak untuk memanfaatkan dan atau menggunakan hak atas kekayaan intelektual atau penemuan ciri khas usaha yang dimiliki pihak lain dengan suatu imbalan berdasarkan persyaratan dan atau penjualan barang atau jasa.

${ }^{3}$ Ilham M. Wijaya "Menyiapkan Kaum Muda Jadi Wirauswasta" artikel diakses pada 16 Maret 2009 dari http://www.mail-archive.com 
Berdasarkan penelitian yang dilakukan oleh US Departement of Commerce SBA dan beberapa lembaga studi lainnya, ${ }^{4}$ bahwa tingkat sukses terwaralaba sebesar 95\% sedangkan pada bisnis biasa (independent) hanya 10\%-35\%. Tingkat keberhasilan sebagai pewaralaba lebih tinggi, hamper 99\%. Bila data diatas dibaca terbalik, tingkat kegagalan terwaralaba $5 \%$, sedangkan pada bisnis bisnis biasa mencapai 65\%-90\%, dan tingkat kegagalan sebagai pewaralaba hanya $1 \%$.

Pada saat ini bisnis franchise atau waralaba di indonesia, semakin menjamur dan banyak diminati oleh masyarakat untuk mencari peluang baru, dari mulai waralaba lokal seperti Ayam bakar Wong Solo, Es Teller 77, Burger Mr.Edam,Alfa Mart, Indomart dan lain-lain. Sampai waralaba mancanegarapun semakin banyak diminati seperti KFC, Mc.Donalds, Hoka-Hoka Bento, Starbuck Coffiee dan lain sebagainya.

Dapat dilihat dari pertumbuhan franchise di Indonesia dari tahun ke tahun semakin meningkat, pada tahun 2006 jumlah franchise bertambah menjadi 450 yang terdiri dari 230 dan 220 franchise asing. Pada tahun 2007 jumlah franchise bertambah dua kali lipat menjadi 700 yang terdiri dari 450 franchise lokal dan 250 franchise asing. Dan pada tahun 2008 dominasi franchise lokal mengingkat 2,5 kali lipat dari franchise asing yang berjumlah 250 , dengan total franchise 850 disertai pertumbuhan franchise lokalnya yang berjumlah 600 . Bahkan di prediksi pertumbuhan franchise di Indonesia melaju dengan kencang. ${ }^{5}$

Itu menandakan franchise punya potensi usaha besar di Indonesia. Namun dalam perkembangannya ada hal-hal yang perlu di perhatikan dalam franchise ini. tidak semua franchise mampu memberikan prospek usaha yang menjanjikan. Kadang kala suatu investasi di bidang franchise tidak lebih menguntungkan dengan melakukan investasi di dunia perbankan, walaupun franchise ini sifatnya lebih produktif. Sehingga perlu mengetahui lebih dalam tentang franchise.

Dalam franchise sering dijumpai istilah-istilah seperti franchise fee,

${ }^{4}$ Amir karamoy, Menjadi Kaya Lewat Waralaba, (Jakarta, Pustaka Bisnis Indonesia, Oktober, 2005), Cet I, hal 25 dan 66

5 "Pertubuhan Franchise di Indonesia", di akses pada 16 Maret 2009 dari http://www. franchisorindonesia.com 
royalti fee, advertising fee dan fee lainnya. Istilah-istilah tersebut memiliki fungsi masing-masing yang akan menentukan prospek usaha. Hal itu akan membantu kita melihat keuntungan yang akan kita peroleh dalam bisnis franchise tersebut. Semuanya merupakan bagian dari sistem franchise, setiap franchise mempunyai perhitungan masing-masing dengan perhitungan secara matang.

\section{Gambaran Umum Franchise}

Kata Franchise berasal dari bahasa Prancis kuno yang berarti "kejujuran atau kebebasan". Pada abad pertengahan franchise diartikan sebagai "hak utama atau kebebasan. ${ }^{6}$ Dalam kamus Besar Bahasa Indonesia definisi waralaba adalah kerja sama dalam bidang usaha dengan bagi hasil sesuai dengan kesepakatan, hak kelola, hak pemasaran. ${ }^{7}$ Sedangkan dalam kamus Ekonomi franchise adalah hak kelola,yaitu suatu hak khusus yang diberikan oleh suatu usaha manufaktur atau organisasi jasa franchise kepada pialang untuk menjual atau pemilik franchise di suatu wilayah tetentu tanpa ekslusivitas. Pengaturan seperti itu kadangkala disahkan dalam suatu perjanjian hak kelola yang merupakan kontrak antara pemilik hak kelola dan pemegang hak kelola. ${ }^{8}$

Sedangkan Hadjowidiadjo mengemukakan definisi franchise sebagaimana dikutip oleh Lindawaty Sewu Sebagai suatu sistem usaha yang khas atau memiliki ciri mengenai bisnis di perdagangan atau jasa berupa jenis produk dan bentuk yang di usahakan, identitas perusahan (logo, desain, merek bahkan termasuk pakaian karyawan), rencana pemasaran dan bantuan operasional.

Dalam beberapa literatur pengertian harfiah franchise lebih menekankan pada semangat kebebasan dan kemandirian (free from

${ }^{6}$ Johannes Ibrahim, Lindawati Sewu, Hukum Bisnis; Dalam Perspektif Manusia Modern, (Bandung: PT. Refika Aditama, 2004) h.122

${ }^{7}$ Departemen Pendidikan Nasional, Kamus Besar Bahasa Indonesia, (Jakarta: Balai Pustaka, 2005), h. 1268

${ }^{8}$ Sumadji P, Yudha Pratama, Kamus Ekonomi Lengkap, (Jakarta: WIPRESS, 2000), h. 327 
servitude). ${ }^{9}$ Berbeda sekali dengan masyarakat kita yang mengartikan franchise sebagai waralaba. Wara artinya lebih, dan laba berarti untung, jadi waralaba berarti lebih untung. Semangat yang dikedepankan adalah semangat untung (profit oriented) sedangkan bagi orang luar, yang penting bisa mandiri dulu keuntungan menyusul kemudian.

Maka dari beberapa definisi diatas penulis mendefinisikan bahwa franchise adalah suatu kerjasama (kemitraan) dalam sistem bisnis/usaha dimana wirausaha kuat memberikan hak penggunaan merek dagang produk atau jasa kepada wirausaha lemah dengan syarat-syarat tertentu sesuai dengan kesepakatan.

\section{Elemen-elemen Pokok dalam Franchise}

Dari pengertian yang telah dipaparkan diatas menunjukan bahwa franchise pada dasarnya mengandung elemen-elemen pokok sebagai berikut: ${ }^{10}$

a. Franchisor (Pemberi Waralaba) yaitu badan usaha atau perorangan yang memberikan hak kepada pihak lain (franchisee) untuk memanfaatkan segala ciri khas usaha dan segala kekayaan intelektual seperti nama, merek dagang, dan sistem usaha yang dimilikinya.

b. Franchisee (Penerima Waralaba) yaitu badan usaha atau perorangan yang diberikan hak untuk memanfaatkan atas kekayaan intelektual atau penemuan atau ciri khas yang dimiliki pemberi waralaba.

c. Adanya penyerahan hak-hak secara eksklusif (dalam praktik meliputi berbagai macam hak milik intelektual/hak milik perindustrian) dari franchisor ke franchisee

d. Adanya penetapan wilayah tertentu, franchise area dimana franchisee diberikan hak untuk beroperasi di wilayah tertentu.

e. Adanya imbal-prestasi dari franchisee kepada franchisor yang berupa initial fee ( franchise fee, investasi untuk fixed asset dan modal kerja untuk operasi selama beberapa bulan usaha) dan royalies serta biayabiaya lain yang disepakati oleh kedua belah pihak.

${ }^{9}$ Hendry E. Ramdhan, Franchise untuk Orang Awam, (Jakarta: PT.Gramedia Pustaka Utama, 2009), h. 2

10 "waralaba"diakses pada 5 Maret 2009 dari http://www.wikipedia.com 
f. Adanya standar mutu yang ditetapkan oleh franchisor bagi franchisee, serta supervisi secara berkala dalm mempertahankan mutu.

g. Adanya pelatihan awal, pelatihan yyang bersifat kesinambungan, yang diselenggarakan oleh franchisor guna peningkatan keterampilan.

\section{Tipe-Tipe Franchise}

Secara umum, sistem perwaralabaan (franchising) dibedakan menjadi dua kategori besar yaitu Waralaba Produk dan Waralaba Merek Dagang, serta Waralaba Format Bisnis. L.eon C. Megginson dan kawan-kawan membagi dua tipe sistem kewaralabaan sebagai berikut ${ }^{11}$ :

a. Waralaba Produk dan Merek Dagang (Product and Trademark Franchising)

Waralaba Produk dan Merek Dagang adalah bentuk waralaba yang paling sederhana, dalam fomat ini franchisor memberikan kepada franchisee hak untuk menjual secara luas suatu produk atau brand tertentu. Atas pemberian izin tersebut biasanya pemberi waralaba memperoleh suatu bentuk pembayaran royalti dimuka dan selanjutnya pemberi waralaba memperoleh keuntungan (yang sering disebut dengan royalty fee) melalui penjualan produk yang diwaralabakan kepada penerima waralaba. ${ }^{12}$ Sedangkan dalam product and tradename (atau sering disingkat product franchise), pemberi waralaba menghasilkan produk dan penerima waralaba menyediakan outlet untuk produk yang dihasikan pemberi waralaba.

b. Waralaba Format Bisnis (Business Format Franchising)

Waralaba Format Bisnis adalah pemberian sebuah lisensi dimana Franchisor memberikan kepada franchisee hak untuk memasarkan suatu produk dan merek dagang tertentu serta menggunakan sistem operasi lengkap dari franchisor. ${ }^{13}$ Dalam Business Format Franchising (atau disebut operating system Franchises), penerima waralaba diberi

${ }^{11}$ Lukman Hakim, Info Lengkap Waralaba , (Yogyakarta: MedPress, 2008)h.21-22

12 Gunawan Widjaja, Seri Hukum Bisnis; waralaba, (Jakarta, PT. Raja Grafindo Persada, 2003), cet.ke-3, h.13

${ }^{13}$ Hakim, Info Lengkap Waralaba, h. 22 
lisensi untuk berusaha dengan menggunakan paket bisnis dan merek dagang yang telah dikembangkan oleh pemberi waralaba.

\section{Aspek Hak Cipta dalam Franchise}

Sebelum pembahasan pengertian hak cipta maka maka perlu sedikit diketahui sedikit latar belakang di keluarkannya Undang-Undang No.19 Tahun 2002, semula berawal dari UU No.6 Tahun 1982 dengan beberapa kali revisi. Lahirnya UHC 1982, sekaligus mengakhiri masa berlakunya Auteurwet 1912 Stb. No. 600, peraturan perundang-undangan yang disebut terakhir ini baru 5 tahun diberlakukan yang menurut terminologi UHC 1982, atas desakan masyarakat internsional terutama Amerika Serikat dan kebutuhan perlidungan hak cipta dalam negeri, UHC 1982 direvisi dengan UU No.7 Tahun 1987, terakhir disempurnakan lagi dengan UU No.19 Tahun 2002. ${ }^{14}$

Upaya pemberian perlindungan terhadap pemilik/penemu ide baru dikenal dengan istilah Intelektual Property Right atau Hak Atas Kekayaan Itelektual (HaKI). Menurut Kasubdit Direktoral Merek Dephukham Yuslisarningsih, persoalan HaKI sendiri merupakan sesuatu yang sangat kompleks karena meluputi berbagai masalah. Menurutnya, "HaKI merupakan asset bisnis yang mencakup hak paten, desain industri, merek dagang dan rahasia dagang." Sedangkan menurut Gunawan Widjaja, seorang advokat dan konsultan hukum bisnis, setiap ide bisnis yang lahir dari seseorang pada dasarnya juga merupakan kekayaan intelektual orang yang bersangkutan dan dilindungi oleh hukum. ${ }^{15}$ Dalam padangan hukum menurut Gunawan, HaKI adalah suatu benda abstrak yang dituang menjadi suatu produk, baik barang maupun jasa yang mampu menghasilkan suatu yang superior dari sebelumnya.

Unsur yang terpenting dalam franchise adalah masalah hak cipta dalam franchise meliputi logo, merek, buku petunjuk pengorganisasian bisnis, brosur atau pamplet serta arsitektur tertentu yang berciri khas dari usahanya. Merek dan know how itu adalah suatu benda, benda immateril

${ }^{14}$ H. OK. Saidin, Aspek Hak Kekayaan Intelektual, cet. 4,(Jakarta: PT. Raja Grafindo Persada, 2004), h. 56-57

${ }^{15}$ Hakim, Info Lengkap Waralaba, h.54-55 
yang termasuk dalam hak atas kekayaan intelektual (HaKI). Perwujudan dari hak atas kekayaan intelektual itu dapat dilihat dalam bentuk, produk, logo deasin, pakaian, penanpilan karyawan dan lain-lain. Adapun imbalan dari penggunaan hakcipta ini adalah pembayaran fee awal dari franchisor kepada franchisee. ${ }^{16}$

Karya Cipta merupakan kemaslahatan umum yang hakiki oleh sebab itu, hak para penciptanya perlu dilindungi dengan undang-undang dalam rangka menjaga hak dan kepentingannya demi menegakan keadilan di tengah masyarakat. Penalaran ini sesuai dengan jiwa dan tujuan syari'ah untuk mengambil maslahat dan menolak madlarat. ${ }^{17}$

\section{Aspek Pembiayaan dalam Franchise}

Ketika kita akan membeli franchise maka kita harus mengluarkan sejumlah biaya atau dana yang sering disebut dengan Fee. Fee adalah biaya yang harus dikeluarkan oleh penerima hak waralaba (franchisee) kepada pemberi waralaba (franchisor), pada umumnya fee dihitung secara persentase berdasarkan omset penjualan kotor. Fee diberikan secara periodik mengikuti laporan penjualan yang dikeluarkan secara teratur pula.

Pada umumnya dalam aspek pembiyaan dalam franchise dikenal ada dua jenis Fee yaitu franchise fee dan royalti fee. Selain kedua fee ini, ada juga franchisor yang menambahkan advertising fee atau marketing dan invesment franchise.

Pertama, Franchise Fee (biaya waralaba awal). Franchise fee adalah biaya pembelian hak franchise yang dikeluarkan oleh franchisee setelah dinyatakan memenuhi persyaratan sebagai franchisee sesuai kriteria franchisor. Umumnya franchise fee dibayarkan satukali saja dan biasanya biaya ini akan diberikan kepada franchisee dalam bentuk fasilitas pelatihan awal dan dukungan set up awal dari outlet pertama yang akan dibuka franchisee.

${ }^{16}$ Darmawan Budi Suseno, Waralaba; Bisnis Minim Resiko Maksim, (Yogyakarta: Pilar Humania, 2005), h. 84

${ }^{17}$ Abu Ahmadi ., Sistem Ekonomi Islam; Prinsip-prinsip dan tujuannya ( Surabaya: Bina Ilmu, 1990) h. 150 
Atau biasanya disebut fee saja, biaya ini dibebankan kepada franchisee untuk semua jenis jasa yang disediakan termasuk biaya rekruitmen sebesar biaya pendirian yang dikeluarkan oleh franchisor untuk kepentingan franchisee. ${ }^{18}$

Jumlah dan jangka waktu pembayaran awal dicantumkan di dalam perjanjian. Pembayaran yang telah diserahkan sepenuhnya menjadi milik franchisor dan tidak dapat dikembalikan kecuali disebutkan dalam perjanjian.

Kedua, royalty fee. Royalti sering disebut uang waralaba terus-menerus. Uang tersebut merupakan pembayaran atas jasa terus-menerus yang diberikan kepada franchisor. Dalam praktiknya, uang tersebut dihitung dalam bentuk dalam bentuk prosentase dari pendapatan kotor franchisee. Biaya royalti yang ditarik oleh franchisor secara rutin diperlukan untuk membiayai pemberian bantuan teknik, manajemen, atau promosi kepada franchisee secara berkelanjutan selama kedua pihak terikat dalam perjanjian. Umumnya dalam perjanjian waralaba disebutkan bahwa franchisee membayar sejumlah biaya waralaba (royalti) kepada franchisor berdasarkan penjualan penjualan kotor perbulan. ${ }^{19}$

Sedangakan besarnya fee awal royalti masing-masing perusahaan yang menganut waralaba memang berbeda-beda. Tidak semua jenis fee atau royalti disyaratkan franchisor. Setiap franchisor mempunyai kebijakan tersendiri dalam menentukan jenis fee atau royalti fee.

Ketiga, advertising fee. Advetising Fee adalah biaya yang dibayarkan penerima hak waralaba (franchisee) kepada pemberi hak waralaba (franchisor) untuk membiayai belanja iklan dari franchisor yanbg disebarluaskan secara nasional atau internasional. Biaya ini dikenakan dengan alasan bahwa tujuan dari jaringan waralaba adalah membentuk suatu skala ekonomi yang demikian besar sehingga biaya-biaya peroutletnya menjadi sedemikian efisien untuk bersaing dengan usaha sejenis. Mengingat iklan dirasakan manfaatmya oleh seluruh jaringan, maka setiap anggota jaringan diminta memberikan kontribusi dalam bentuk

\footnotetext{
${ }^{18}$ Suseno, Waralaba; Bisnis, h. 55

${ }^{19}$ Ramdhan, Franchise untuk Orang Awam, h. 14
} 
advertising fee. Besarnya biaya ini maksimum 3\% dari penjualan, tidak semua franchisor memberlakukan advertising fee bagi franchisee-nya. ${ }^{20}$

Keempat, investment franchise. Investment Franchise adalah konrak bisnis dimana franchisee menyetor modal yang substansial untuk memodali bisnis yang kategorinya mahal, kendati mempertahankan keseluruhan tim manajemen strategis, mereka juga menyewa beberapa manajer profesional untuk memimpin cabangnya. ${ }^{21}$

Dan masih banyak lagi istilah-istilah yang sering dijumpai dalam franchise yang masing-masing mepunyai pengertian berbeda, namun semuanya merupakan bagian bagian sistem franchise yang berkaitan dengan Pricing Policy Franchisor dan penentuannya tidak bisa seenaknya harus melalui perhitungan secara matang.

Dalam menentukan Pricing Policy Franchisor ada tiga langkah yang bisa dilakukan. Pertama, yang paling gampang dan umum dilakukan, adalah market oriented method, yang berarti membandingkan dengan situasi pasar yang ada. Metode pertama ini franchisor harus memiliki confident untuk mengetahui posisinya diantara pasar. "Kalau tidak punya confident akan susah," ujarnya. Kedua, adalah cost oriented method. Dasarnya adalah berapa cost yang diperlukan untuk menjual dan berapa keuntungan yang akan diambil. Ketiga, pendekatan yang disebut customer oriented method. Artinya pricing policy diukur dari referable customer bukan dari kemampuan customer. Dari ketiga metode tersebut lanjut Burang, sebagai seorang calon franchisor harus bisa mencari jalan mana yang paling pas. $^{22}$

\section{Aspek Legalitas Waralaba}

Di Indonesia waralaba sebagai suatu bentuk perjanjian, tunduk pada ketentuan umum yang berlaku bagi sahnya suatu perjanjian sebagaimana diatur dalam Buku III kitab Undang-undang Hukum Perdata. Selain itu

\footnotetext{
${ }^{20}$ Hakim, Info Lengkap Waralaba, h 207

${ }^{21}$ Ibid., 210

22 "Menentukan Franchise Fee dan Royalty Fee" diakses pada 25 Mei 2009 dari http:// www.InfoFranchisecommunity.blogspot.com
} 
secara khusus, waralaba di Indonesia diatur antara lain melalui ${ }^{23}$ :

a. Peratuan Pemerintah Republik indonesia Nomor 16 Tahun 1997 tanggal 18 Juni 1997 tentang Waralaba.

b. Keputusan Menteri Perindustrian dan Perdagangan Republik Indonesia Nomor 259/MPP/KEP/7/1997 tanggal 30 Juli 1997 tentang Ketentuan dan Tata Cara Pelaksanaan Pendaftaran Waralaba. ${ }^{24}$

Awalnya waralaba di Indonesia tidak mempunyai aturan hukum yang mengatur perjanjian waralaba. Baru pada tahun 1997 terbitlah Peraturan Pemerintah (PP) Nomor 16 tahun 1997 tentang waralaba. Pasal 1 PP ini menyatakan bahwa: " waralaba adalah perikatan dimana salah satu pihak diberikan hak untuk memanfaatkan dan atau menggunakan hak atas kekayaan intelektual atau penemuan atau ciri khas usaha yang dimiliki pihak lain dengan suatu imbalan berdasarkan persyaratan dan atau penjualan barang dan atau jasa. ${ }^{25}$ Dari rumusan pasal tersebut dapat diuraikan hal-hal sebagai berikut: ${ }^{26}$

a. waralaba merupakan suatu perikatan

Waralaba sebagai suatu perikatan harus tunduk pada ketentuan umum mengenai perikatan yang diatur dalam kitab Undang-undang Hukum Perdata (KUHPerdata) tentang perjanjian (pasal 1313), sahnya perjanjian (Pasal 1320) dan ketentuan Pasal 1338. Dengan demikian, apabila pihak pemberi waralaba pihak asing dan penerima waralaba adalah orang Indonesia, maka perjanjian terikat pada PP Nomor 16 Tahun 1997 tentang waralaba. ${ }^{27}$

b. Waralaba melibatkan hak untuk memanfaatkan dan atau menggunakan hak atas kekayaan intelektual atau penemuan ciri khas usaha, yang meliputi antara lain merek, nama dagang, logo, desain, hak cipta, rahasia dagang dan paten. Sedangkan yang dimaksud dengan penemuan atau ciri khas usaha misalnya sistem manajemen,

\footnotetext{
${ }^{23}$ Saidin, Aspek Hak Kekayaan Intelektual, h. 517

${ }^{24}$ Hakim, Info Lengkap Waralaba, h 50

${ }^{25}$ Ibid., 50

${ }^{26}$ Widjaja, Seri Hukum Bisnis; waralaba, h. 106

${ }^{27}$ Hakim, Info Lengkap Waralaba, h 51
} 
cara penjualan atau penataan atau cara distribusi yang merupakan karakteristik khusus dari pemiliknya.

Hanya saja dalam PP No. 16 Tahun 1997 tidak menjelaskan format dan bentuk harus otentik dalam akta notaris, tapi dalam PP ini ditentukan perjanjian waralaba harus dibuat secara tertulis dalam bahasa Indonesia (Pasal 2 Ayat 1 dan 2). ${ }^{28}$

c. Waralaba diberikan dengan suatu imbalan berdasarkan persyaratan dan atau penjualan barang dan atau jasa. Ketentuan ini pada dasaranya menekankan kembali bahwa waralaba tidaklah diberikan dengan cuma-Cuma. Pemberian waralaba senantiasa dikaitkan dengan suatu bentuk imbalan tertentu yang secara umum dikenal ada dua macam atau dua jenis yaitu yang pertama, kompansasi langsung dalam betuk moneter (direct monetary conpensation) yang dikenal dengan franchise fee dan royalty fee. Dan yang kedua adalan kompensasi tidak langsung yang dalam bentuk nilai moneter (indirect and nonmonetary conpensation) antara lain;

1) Keuntungan sebagai akibat dari penjualan barang modal atau bahan mentah (bahan setengah jadi dan barang jadi) yang merupakan satu paket dengan pemberian waralaba.

2) Pembayaran dalam bentuk dividen ataupun bunga pinjaman dalam hal pemberi waralaba juga turut memberikan bantuan financial dalam bentuk ekuitas (equity participation) atau dalam wujud pinjaman (loan) jangka pendek maupun jangka panjang.

3) Cost Shifting atau pengalihan atas sebagian biaya yang harus dikeluarkan oleh pemberi waralaba. Pengalihan ini biasanya dilakukan dalam bentuk kewajiban bagi penerima untuk mengeluarkan segala biaya yang diperlukan untuk mencegah terjadinya pelanggaran maupun untuk mempertahankan perlindungan $\mathrm{HaKI}$ yang termasuk dalam paket yang diwaralabakan.

4) Perolehan data pasar dari kegiatan usaha yang dilakukan oleh penerima lisesnsi. Dengan ini berarti pemberi waralaba memiliki akses yang lebih untuk mengembangkan waralabanya.

${ }^{28}$ Ibid., 51 
Dengan persyaratan pernyataan "berdasarkan persyaratan dan atau penjualan barang atau jasa", jelas kompensasi yang diizinkan dalam pemberian waralaba menurut peraturan pemerintah No.16 Tahun 1997 ini hanyalah imbalan dalam bentuk Direct Monetary Conpentation.

Keterangan-kterangan berikut harus didaftarkan di Departemen Perindustrian dan Perdagangan oleh penerima waralaba paling lambat 30 hari sejak berlakunya waralaba jika tidak dilakukan maka pencabutan izin usaha perdagangan (SIUP) dapat dilakukan.

Hingga sampai saat ini pemerintah mulai menaruh perhatian lebih pada industri franchise. Pemerintah menerbitkan PP. No. 42 Tahun 2007 yang merupakan reivisi peratuaran pemerintah sebelumnya. Peraturan ini secara khusus mengatur waralaba. Pada tahun 2008 pemerintahpun mengeluarkan PERMENDAG No. 31 Tahun 2008, sebagai petunjuk pelaksanaan PP tersebut. ${ }^{29}$

\section{Franchise Syariah}

Di dalam konteks fiqh klasik memang tidak dikenal istilah Fanchise atau waralaba. Jika dilihat dari pola bisnis franchise ini, layaknya ekonomi islam melakukan sharing. Prinsip dalam ekonomi islam, penentuan fee harus dengan cara yang adil yaitu untung sama-sama di bagi,rugi sama-sama ditanggung. Fee yang adil dalam waralaba adalah fee yang ditawarkan menggambarkan paket dukungan dan infrasrtuktur yang akan di berikan kepada franchisor. ${ }^{30}$

\section{Tinjauan dari Aspek Hak Cipta}

Apabila kita amati dari aspek terpenting dalam system waralaba ini adalah masalah hak cipta. Hakcipta dalam khazanah hokum Islam termasuk hal yang baru, akan tetapi beberapa ahli hukum Islam telah berusaha untuk membahasnya seperti Fathi Daroini menyebut hak cipta sebagai Haqqul

${ }^{29}$ Hendry E. Ramdhan, Franchise Untuk Orang Awam, (Jakarta: PT. Gramedia Pustaka Utama, 2009) h. 73

${ }^{30}$ Siti Nazma, Bisnis Syariah dari Nol; Langkah Jitu Menuju Kaya, Penuh Berkah dan Bermakna (Jakarta: Hikmah, 2008)h.180. 
Ibtikar. Karya cipta bersumber dari hasil pemikiran merupakan jalan bagi perkembangan dan kemajuan kebudayaan manusia.

Hasil pikiran itu jikalau dilihat dari kacamata fiqh Islam bisa dimaksukkan dalam kategori manfaat, bukan benda. Hal ini dapat dilihat dari hadits yang mengatakan:

"Apabila seorang manusia meninggal dunia, terputuslah segala amal perbuatannya, kecuali tiga hal: sedekah jariah, ilmu yang bermanfaat, dan dimanfaatkan oleh orang lain, anak shaleh yang mendo'akan orang tuanya."(H.R. Ahmad bin Hanbal dari Abi hurairah, hadits Musnad bin hanbal)

Hadits ini memberi pengertian bahwa ilmu adalah amal (perbuatan) dan manfaat. Dengan memanfaatkan hasil karya cipta orang yang pandai berarti melanjutkan amal salehnya yang tidak terputus oleh kematiannya. Ilmu adalah merupakan sumbermanfaat secara syrai'at yang tidak ada bekasnya meskipun penciptanya telah meninggal.

Seorang penggagas atau pencipta merupakan sesuatu yang menunggal yang bersifat kekayaan (property) yang melekat pada dirinya, dan hak ekslusif ada pada kekuasaanya, sehingga seorang penggagas berhak mengalihkan hak ccipta atas ciptaanya kepada pihak lain, baik melalui pewarisan, hibah, wasiat, perjanjian tertulis maupun sebab-sebab lainya yang dibenarkan oleh undang-undang, harus dilakukan secara tertulis maupun tidak dengan atau tanpa aktanotaris. Hal ini sesuai dengan penjelasan pasal 3 UUHC No. 19 tahun 2002. ${ }^{31}$

Mengenai konteks tentang karya cipta intelektual merupoakan suatu aset dan kekayaan (property) yang memiliki nilai ekonomis (Ekonomic Value)bagi pencipta atau pemegang hak cipta. Beberapa ulama mendefinisikan kakayaan atau/harta (maal), yaitu "sesuatu yang secara naluri manusia cenderung padanya dan memungkinkan untuk disimpan sampai waktu yang diperlukan".

Jika terjadi pelanggaran terhadap hak tersebut, franchisor berhak untuk mengajukan gugatan untuk mendapatkan ganti rugi dan penghentian

${ }^{31}$ Abdul Manaf, Himpunan Peraturan Perundang-undangan dibidang Hak Kekayaan intelektual?HaKI (undang-undang hak Cipta No 19 Tahun 2002), (Bandung: Mandai maju, 2004), h.314. 
semua perbuatan yang berkaitan dengan penggunaan merek tersebut, setidaknya harus menghindari unsur dibawah ini:

1. Bertentangan dengan undang-undang, agama kesusilaan dan ketertiban umum.

2. Tidak memiliki daya pembeda.

3. Tidak menjadi milik umum.

4. Merupakan sesuatu yang berkaitan dengan barang atau jasa yang dimohonkan pendaftarannya.

Dalam kajian fiqh, merek dapat dimasukan dalam haq ibtikar, yang berarti awal atau permulaan, maksudnya hak cipta atau kreasi yang dihasilkan oleh seseorang untuk pertamakali atau boleh berbentuk suatu penemuan sebagai perpanjangan dari teori sebelumnya. ${ }^{32}$ Hak cipta memiliki waatk tersendiri, merupakan buah dari hasil karya otak manusia. Menurut ulama fiqh Al-Azz bin Abussalam, apabila dilihat dari sisi materialnya, ibtikar lebir serupa dengan manfaat hasil sesuatu materi seperti buah-buahan dari pohon, susu hewan perahan. Ia berkata tetang pentingnya suatu manfaat, seraya berkata:"Tujuan utama dari suatu harta adalah manfaatnya."

MUI mengeluarkan fatwa khusus berkaitan dengan perlindungan HaKI, yaitu fatwa MUI No.1 Thaun 2003 tentang Hak Cipta. ${ }^{33}$ Pendapat MUI menggolongkan hak cipta sebagai barang berharga yang boleh dimanfaatkan secara syara' (hukum islam). Dengan landasan "mayoritas ulama dari kalangan Mazhab Maliki, Syafi'i dan Hambali berpendapat bahwa hak cipta atas ciptaan yang orisinal dan manfaat tergolong harta berharga, sebagaimana benda boleh dimanfaatkan secara syara' (hukum islam). Seperti yang telah dipaparkan sebelumnya, merek (kekayaan inteltual) merupakan sesuatu harta ternilai yang bermanfaat, oleh karena itu dapat dinilai dengan uang, maka dapat disimpulkan bahwa hak cipta dapat dimanfaatkan dan digolongkan sebagai benda berharga, karena itu

${ }^{32}$ Budi Agus Riswadi, Hak Kekayaan Intelektual dan Budaya Hukum, (Jakarta: PT.Raja Grafindo Persada, 2004), h.85

${ }^{33}$ Fatwa MUI tentang Perlindungan Hak Kekayaan Intelektual (HaKI), http://www. mui.or.id, diakses pada 12 september 2008 
diperbolehkan bagi pihak yang mempunyai Hak Cipta tersebut mengambil imbalan yang berupa franchise fee dan royalti fee atas Hak Ciptanya.

Hal ini didukung oleh para ulama fiqh yang menyatakan bahwa sesuatu yang dapat bermanfaat yang halal boleh diambil oleh karenanya boleh bagi pemilik mengambil imbalannya.

\section{Tinjauan dari Aspek Franchise Fee \& Aspek Royalty fee}

Seperti yang telah dipaparkan sebelumnya bahwa Merek (kekayaan Intelektual) merupakan suatu harta ternilai yang bermanfaat, oleh karena itu dapat dinilai dengan uang. Maka diperbolehkan bagi franchisor untuk memberikan haknya kepada orang lain dengan mengharapkan imbalan yaitu berupa Franchise fee dan royalty fee.

Ada dua hal yang menjadi pertimbangan dalam melakukan aktivitas ekonomi secara islam yaitu harus adanya kerelaan dan keadilan dalam Franchise tersebut. Hal ini sesuai dengan dasar utama dalam bermuamalah yaitu sukarela atu kerelaan. Kesesuian dengan firman allah swt:

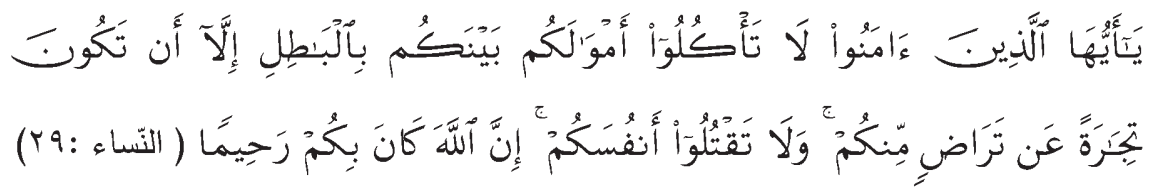

Hai orang-orang yang beriman, janganlah kamu saling memakan harta sesamamu dengan jalan yang batil, kecuali dengan jalan perniagaan yang Berlaku dengan suka sama-suka di antara kamu. dan janganlah kamu membunuh dirimu. Sesungguhnya Allah adalah Maha Penyayang kepadamu. (Q.S: 4: An-Nissa: 29). ${ }^{34}$

Sedangkan dasar yang lain adalah keadilan, karena keadilan inilah yang menjadi tujuan utama sehingga tercapai kebahagiaan dunia akhirat. Kosep keadalilan dalam ekonomi islam sendiri ialah "tidak mendzalimi dan tidak pula didzalimi". Keadilan merupakan suatu esensi dalam sistem ekonomi islam. Sebagaimana dalam firman Allah SWT (Q.S: 38: Shad: 24):

${ }^{34}$ Depag RI, Alquran dan Terjemahnya, (Arab Saudi: Mujamma' al-Malik Fahd Thiba' At Al- Mush-Haf Asy-Syarif, 1415 H) h.122 


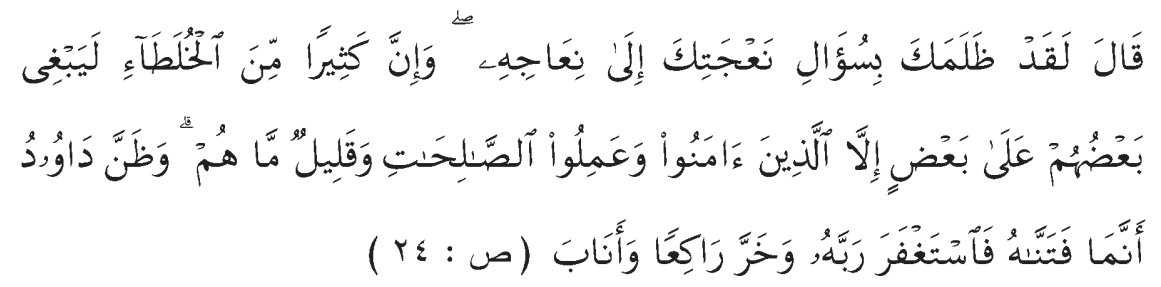

Daud berkata: "Sesungguhnya Dia telah berbuat zalim kepadamu dengan meminta kambingmu itu untuk ditambahkan kepada kambingnya. dan Sesungguhnya kebanyakan dari orang-orang yang berserikat itu sebahagian mereka berbuat zalim kepada sebahagian yang lain, kecuali orang-orang yang beriman dan mengerjakan amal yang saleh; dan Amat sedikitlah mereka ini. dan Daud mengetahui bahwa Kami mengujinya; Maka ia meminta ampun kepada Tuhannya lalu menyungkur sujud dan bertaubat." (Q.S: 38: Shad: 24). ${ }^{35}$

Konsep islam dalam bermuamalah amat jelas setiap individu bebas dalam membuat perjanjian yang belum ada ketentuanya dalam syariah, selama tidak bertentangan dengan syara' dan tidak pula bertentangan dengan hakekat perjanjian itu sendiri termasuk didalamnya menentukan besaran franchise fee dan royalty fee. Asalkan sepanjang kebebasan itu dapat dipertanggung jawabkan baik secara sosial maupun dihadapan Allah. ${ }^{36}$

Mengenai penetapan franchise fee ini sebagian kalangan ada yang mengatakan bahwasannya dalam franchise syariah memiliki karakteristik antaralain:

1. Tidak mengenal adanya Franchise Fee. Hal ini dikarenakan usaha belum berjalan. Setiap keuntungan akan dinikmati setelah usaha berjalan dan ada keuntungan.

2. Royalty Fee atau lebih tepatnya bagi hasil diambil dari gross profir atau net profit. Bisa di hitung bulanan, 3 bulanan atau sesuai kesepakatan. ${ }^{37}$

3. Usaha tersebut menjadi milik bersama. Proporsi kepemilikan saham

${ }^{35}$ Depag RI, Alquran dan Terjemahnya, (Arab Saudi: Mujamma' al-Malik Fahd Thiba' At Al- Mush-Haf Asy-Syarif, 1415 H) h.735

${ }^{36}$ Ibid, h. 17

${ }^{37}$ Hartanto Widodo "Franchise Syariah, Why Not?" artikel diakses pada 7 februari 2009 dari http://boutiquesoftware.wordpress.com//franchise-syariah-why-not/ 
dan bagi hasil ditetapkan berdasarkan kesepakatan kedua belah pihak.

4. Dalam kerjasama ini, franchisee (shahibul maal) bisa terlibat dalam manajemen usaha ataupun tidak.

Sebagaimana disebutkan diatas selama dalam penetapan Franchise fee dan royalty fee ini tidak bertentangan bolehkan. Oleh karena itu kejelasan dan transparansi dalam memulai kontrak ketika membeli franchise sangat penting agar terlihat hak dan kewajiban antara franchisor dan franchisee, jangan sampai ada pihak yang mendzalimi dan dizalimi. ${ }^{38}$

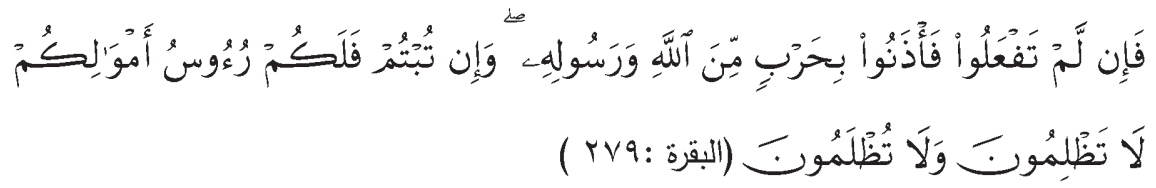

Maka jika kamu tidak mengerjakan (meninggalkan sisa riba), Maka ketahuilah, bahwa Allah dan Rasul-Nya akan memerangimu. dan jika kamu bertaubat (dari pengambilan riba), Maka bagimu pokok hartamu; kamu tidak Menganiaya dan tidak (pula) dianiaya. (Q.S: 2: Al-Baqarah: 279). ${ }^{39}$

\section{Analisis Penetapan akad Musyarakah di Franchise BRC}

Setiap investor (franchisee) yang ingin membuka bisnis franchise BRC harus memenuhi memenuhi kriteria-kriteria yang di terapkan oleh franchisor antara lain ${ }^{40}$ :

1. Prasyarat Calon Terwaralaba (Franchisee)

a Muslim.

b Bertaqwa kepada Tuhan Yang Maha Esa.

c Memiliki visi untuk mengembangkan thibbun nabawi.

d Memiliki kejujuran dan integritas yang tinggi terhadap perusahaan.

${ }^{38}$ Siti Najma, Bisnis Syariah dari Nol; Langkah Jitu Menuju Kaya, Penuh Berkah dan Bermakna,(Jakarta: Hikmah, 2008), h. 118

${ }^{39}$ Depag RI, Alquran dan Terjemahnya, (Arab Saudi: Mujamma' al-Malik Fahd Thiba' At Al- Mush-Haf Asy-Syarif, 1415 H), h.70

${ }^{40}$ Anas Hikmat "Prosedur pengajuan BRC: Prospektif dan Menguntunngkan Sebagai franchisee BRC" didapatkan dari Company Profile BRC, Bandung 5 Agustus 2009. 
e Memiliki semangat kewirausahaan dan keinginan kuat untuk berhasil.

f Bersedia mencurahkan sepenuhnya tenaga, pikiran dan waktunya untuk kegiatan waralaba.

g Memiliki jiwa kepemimpinan (leadership), pribadi yang manarik, ramah, terbuka dan mudah bergaul.

h Memiliki dukungan finansial yang cukup.

Jika semua kelengkapan persyaratan investor telah memenuhi kriteria yang di tetapkan oleh BRC, tahap selanjutnya untuk keseriusan investor harus membuat surat permohonan, dari mulai daftar riwayat hidup, akte pendirian dan profil perusahaan (bagi usaha yang berbadan hukum), bukti kepemilikan bang dengan reputasi yang baik, dan bersedia membuat perjanjian bahwa tidak akan melakukan tindakan diluar standar yang diterapkan.

2. Proses Pengajuan Permohonan ${ }^{41}$

a Kerjasama antara investor dan BRC dilakukan dengan system Mudharabah atau musyarakah atau Franchise Manajemen menentukan jenis kerja sama ini berdasarkan wilayah yang dipilih oleh investor.

b Pihak calon terwaralaba (franchisee) mengajukan surat permohonan beserta analisa marketing perihal tempat yang diajukan sebagai klinik cabang kepada pihak pewaralaba (franchisor) melalui pihak manajemen brc.

c Pihak manajemen akan melakukan seleksi awal berupa pemeriksaan kelengkapan dan keabsahan dokumen pendukung yang terlampir pada surat permohonan.

d Jika dinyatakan tidak memenuhi syarat, maka surat permohonan ditolak sama sekali atau masih perlu dipenuhi kelengkapannya untuk diajukan kembali.

e Apabila dinyatakan memenuhi syarat, maka tahap berikutnya adalah interview/tatap muka dengan pihak manajemen/pemilik

${ }^{41}$ Anas Hikmat "Prosedur pengajuan BRC: Prospektif dan Menguntunngkan Sebagai franchisee BRC" didapatkan dari Company Profile BRC, Bandung 5 Agustus 2009. 
perusahaan (franchisor).

f Apabila dinyatakan memenuhi syarat dalam tahap interview, maka pada tahap berikutnya adalah pihak manajemen/pemilik perusahaan (franchisor) melakukan survey ke lokasi calon klinik cabang dan melihat langsung kondisi fisiknya.

g Bilamana lokasi dan kondisi fisik calon klinik dinyatakan memenuhi syarat, maka tahap berikutnya adalah penandatanganan Memorandum of Understanding (MoU) dan pada saat bersamaan pihak calon terwaralaba (franchisee) diwajibkan menyerahkan uang muka (advance payment) sebesar 10\% dari franchise-fee.

h Apabila calon terwaralaba (franchisee) telah melengkapi sarana dan prasarana operasional termasuk tenaga-kerjanya, maka tahap berikutnya adalah penyerahan sisa franchise-fee sebesar $90 \%$ dan diteruskan dengan penandatanganan Perjanjian Waralaba di hadapan notaris, kemudian dilanjutkan dengan implementasinya, antara lain: orientasi, pelatihan \& simulasi, dan peresmian pembukaan klinik cabang.

Setelah proses seleksi pada calon franchisee telah dilalui maka tahap selanjutnya adalah menentukan kesepakatan kerjasama, pada tahapan ini akad yang digunakan untuk franchisee adalah akad musyarakah. Dalam menetapkan akad ini BRC tidak melakukan akan dengan sembarang orang karena harus memenuhi sertifikasi yang ditetapkan oleh perusahan dalam hal ini BRC sangat selektif untuk menjaga perusahan maka kita serahkan kepada orang yang sudah mendapat sertifikasi BRC ${ }^{42}$.Adapun akad Mudharabah yang ditawarkan oleh BRC yaitu untuk bagi siapa saja para investor yang ingin menanamkan modalnya (berinvestasi) di BRC.

Dari hasil kajian diatas, penulis menganalisis dalam praktek penetapan akad musyarakah pada franchise BRC tidak ada yang bertentangan hukum islam. Pertama, dlilihat dari rukunnya yaitu Al-'Aqidain (Para pihak yang berakad antara franchisor dan franchisee), Ma'qud 'Alayhi (Obyek akad yaitu hak cipta atau penggunaan merek dan produk-produk BRC ) dan Sighah al-'Aqd (pernyataan ijab dan qabul dibuktikan dengan surat perjanjian atau kontrak kerja antara franchisor dan franchisee).

\footnotetext{
${ }^{42}$ Wawancara Pribadi dengan Anas Hikmat. Bandung, 6 Oktober 2009.
} 
Kedua, pada sisi syarat obyek akad pada franchise BRC antaralain obyek Akad harus telah ada ketika akad berlangsung, obyek akad harus mal mutaqawwam (bernilai menurut syara), Bangkai, darah, miras tidak sah diperjual-belikan (produk yang digunakan tidak mengadung unsur zat yang diharamkan, dapat diserahkan ketika akad berlangsung dan yang terakhir yaitu obyek akad harus jelas dan dikenali para pihak.

\section{Analisis Penetapan Franchise Fee Syariah}

Setelah penulis melakukan wawancara pada franchise BRC, dana awal untuk membuka franchise BRC diperlukan dana sebesar Rp 70 juta. Dengan rincian sebagai berikut:
$\diamond$ Francise fee
: Rp 10 juta
$\diamond$ Sewa tempat 1 tahun
: Rp 40 juta
$\diamond$ Set up tempat
: Rp 10 juta
$\diamond$ Pembelian Produk
: Rp 10 juta
Total Investasi Awal
: Rp 70 juta

Dengan pengembalian modal hanya dengan 11 bulan. Untuk itu franchisor menargetkan omzet perhari sebesar sebesar Rp 600 ribu, supaya arus pengembalian sesuai dengan target. Namun perlu diperlukan lokasi usaha yang strategis untuk mempercepat pengembalian modal.

Tabel 4.1

Jumlah Penjualan Pertahun

\begin{tabular}{cccc}
\hline Item & $\begin{array}{c}\text { Target Penjualan / } \\
\text { bulan RP }\end{array}$ & Jumlah bulan & $\begin{array}{c}\text { Penjualan } \\
\text { pertahun }\end{array}$ \\
\hline $\begin{array}{c}\text { Omzet Rp 600.000/ } \\
\text { hari }\end{array}$ & 18.000 .000 & 12 & 216.000 .000 \\
\hline
\end{tabular}

Selain HPP (Harga Pokok Penjualan), biaya yang dibutuhkan adalah gaji untuk 2 orang pegawai, biaya listrik, biaya pembelian produk, royalty fee $10 \%$ perbulan (dari penghasilan Bersih) dan biaya rupa-rupa. 
Tabel 4.2

Jumlah Biaya Pengeluaran Pertahun

\begin{tabular}{cccc}
\hline Item & $\begin{array}{c}\text { Pengeluaran/ } \\
\text { Bulan Rp }\end{array}$ & $\begin{array}{c}\text { Jumlah } \\
\text { Bulan }\end{array}$ & $\begin{array}{c}\text { Pengeluaran/ } \\
\text { Tahun Rp }\end{array}$ \\
\hline Gaji Pegawai (dua orang) & 2.000 .000 & 12 & 24.000 .000 \\
\hline Pembelian Porduk & 8.000 .000 & 12 & 96.000 .000 \\
\hline Listrik & 100.000 & 12 & 1.200 .000 \\
\hline Biaya rupa-rupa & 200.000 & 12 & 2.400 .000 \\
\hline Total Biaya Pengeluaran & 10.300 .000 & 12 & 123.600 .000 \\
\hline
\end{tabular}

Dengan demikian penjualan sebesar Rp 216.000.000 pertahun dan biaya pengeluaran Rp 123.600.000 pertahun, maka profit yang bisa didapat keuntungan pertahun sebesar Rp 83.000.000.

Tabel 4.3

Jumlah Profit

\begin{tabular}{ccc}
\hline Pendapatan Pertahun (TR) Rp & $\begin{array}{c}\text { Pegeluaran Pertahun } \\
\text { (TC) Rp }\end{array}$ & Profit (TR-TC) Rp \\
\hline 216.000 .000 & 123.600 .000 & 83.000 .000 \\
\hline
\end{tabular}

Biasanya pada bulan ke 4 keatas, jumlah pendapatan perbulan bisa meningkat hingga mencapai Rp 25.000.000 juta perbulan. Hal ini terbilang cukup besar karena untuk balik modal akan semakin cepat. Analisa tawaran modal ini khusus untuk wilayah bandung Jika dilihat dari sisi keuangan diatas maka bisnis sangat menjanjikan sebanding dengan franchise fee yang ditetapkan.

Selama perusahaan BRC membuka (menjual) franchise sampai saat ini tidak terdapat cabang BRC (franchisee) yang bangkrut, semuanya terus bertahan dan maju. Walaupun perkemabangannya adanya yang pesat dan ada yang agak lambat karena faktor seperti tempat yang kurang strategis.

Selain itu penggunaan franchise fee sebesar Rp 10.000.000 yang ditetapkan oleh franchise BRC digunakan sebagai biaya konsultasi franchisee, untuk pendampingan franchisee ketika akan membuka franchise BRC dan biaya grand opening franchisee ${ }^{43}$.

Apabila dikaitkan dengan hak cipta, Franchise fee merupakan sebuah

${ }^{43}$ Wawancara Pribadi dengan Anas Hikmat. Bandung, 6 Oktober 2009. 
bentuk penghargaan atas merek (hak cipta) yang akan digunakan oleh franchisee. Serta franchise fee menggambarkan paket dukungan dan infrastruktur yang ditawarkan, maka dapat dipastikan adanya penetapan franchise fee pada Franchise BRC dibolehkan karena tidak bertentangan dengan hukum islam.

\section{Analisis Penetapan Royalti Fee Syariah}

Dalam sebuah hubungan kerjasama fee merupakan sebuah faktor yang paling essensial atau dominan yang memungkinkan seseorang mau bekerja untuk kepentingan bersama, tanpa adanya fee mungkin tidak akan terjalin hubungan kerjasama. Dalam islam dikenal dengan ujrah, ujrah merupakan imbalan dari pemberi kerja kepada penerima kerja untuk sesuatu pekerjaan atau jasa yang telah ada dan akan dilakukan, berlangsung sebagai jaminan kelangsungan yang layak bagi kemanusiaan dan suatu produksi. ${ }^{44}$ Dalam penentuan ujrah (upah) kedua belah pihak harus bersikap jujur dan adil dalam semua urusan agar tidak terjadi tindakan aniyaya terhadap orang lain juga tidak merugikan diri sendiri. Oleh karena itu Al-Quran memerintahkan kepada pemberi kerja untuk membayar pekerja dengan bagian yang seharusnya mereka terima sesuai kerja mereka dan pada saat yang sama dia telah menyelamatkan kepentingannya sendiri ${ }^{45}$

Dalam Islam, upah merupakan salah satu unsur ijârah, selain tiga unsur lainnya; âqid (orang yang berakad), ma'qûd 'alaih (barang yang menjadi objek akad), dan manfaat. Ketentuan pengupahan harus memenuhi syarat-syarat:

1. Adanya kerelaan kedua belah pihak yang berakad.

2. Manfaat yang menjadi akad harus diketahui secara sempurna sehingga tidak muncul masalah di kemudian hari.

3. Objek akad itu sesuatu yang halal atau tidak diharamkan.

4. Upah harus jelas, tertentu dan sesuatu yang bernilai harta.

${ }^{44}$ Heidjarachman Ranupandjojo, Manajemen Personalia, (Yogyakarta: BPEF-UGM, 1990), h.9

${ }^{45}$ Afjalur Rahman, Doktri Ekonomi Islam, (Jakarta: Dana Bhakti Wakaf, 1995), h.363 
Dalam hal besar kecilnya upah, Islam mengakui kemungkinan terjadinya dikarenakan beberapa sebab; perbedaan jenis pekerjaan, perbedaan kemampuan, keahlian, dan pendidikan, pertimbangan bukan keuangan dalam memilih pekerjaan, mobilitas tenaga yang berbeda. Pengakuan perbedaan ini didasarkan pada firman Allah Swt. dalam surat al-Zukhruf ayat 32:

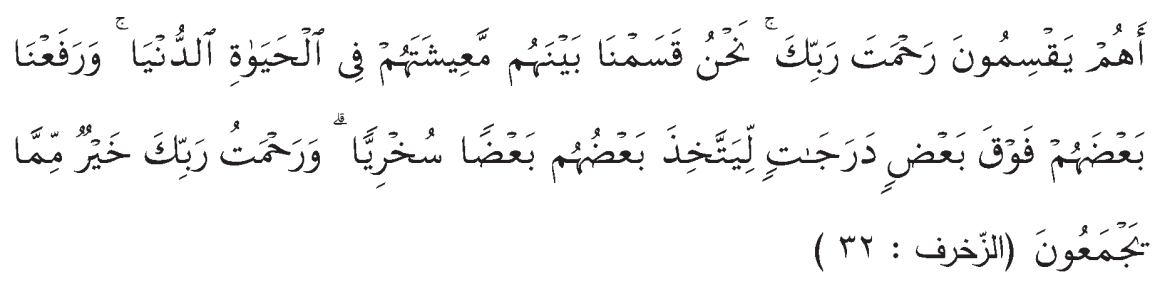

Apakah mereka yang membagi-bagi rahmat Tuhanmu? Kami telah menentukan antara mereka penghidupan mereka dalam kehidupan dunia, dan Kami telah meninggikan sebahagian mereka atas sebagian yang lain beberapa derajat, agar sebagian mereka dapat mempergunakan sebagian yang lain. dan rahmat Tuhanmu lebih baik dari apa yang mereka kumpulkan. (Q.S: 43: Az-zukhruf: 32). ${ }^{46}$

Pada franchise BRC royalty fee ditetapkan sebesar 10\% dari laba bersih franchisee perbulan, sebagai biaya promosi manajamen untuk franchisee adapun fasilitas promise yang didapatkan oleh franchisee yaitu, dipromosikan lewat radio ( seperti: MQ FM untuk diwilayah Bandung dan Dakta FM di Bekasi), brosur-brosur, bulletin bulanan dan terakhir iklan ${ }^{47}$.

Walaupun dalam pelaksanaan adanya penetapan royalty fee $10 \%$ dirasa memberatkan ketika pendapatan masih dibawah 10 juta perbulan ${ }^{48}$,atau ketika 3 bulan pertama dari pembukaan cabang BRC.

Namun jika kita perhatikan dari penggunaan pembayaran royalty sama dengan pemberian upah atau honor kepada franchisor. Karena royalty fee digunakan secara jelas transparan yaitu sebagai biaya promosi manajemen

${ }^{46}$ Alquran dan Terjemahnya (Arab Saudi: Mujamma' al-Malik Fadh Thiba' At Al- MushHaf Asy-Syarif 1415 H) h. 798

${ }^{47}$ Wawancara Pribadi dengan Anas Hikmat. Bandung, 6 Oktober 2009.

${ }^{48}$ Wawancara Pribadi dengan Lukman Hakim. Bandung, 6 Desember 2009. 
untuk kemajuan bersama. Sebagaimana kita ketahui faktor yang paling penting dari penetapan upah atau royalty adalah keadilan. Keadilan merupakan norma yang sangat diutamakan dalam islam.dan diantara tanda keadilan adalah haramnya bermuamalah dengan riba karena riba tidak hanya akan menghancurkan kehidupan individu saja melainkan juga dapat menghancurkan sendi-sendi kehidupan masyarakat. Keadilan itu diaplikasikan dengan akad yang dipakai pada franchise BRC yaitu akad Musyarakah. Royalty Fee dari hasil bersih pendapatan Franchisee sesuai dengan kesepatan yang telah disepakati ketika diawal perjanjian.

\section{Penutup}

Penetapan akad musyarakah pada franchise BRC tidak ada yang bertentangan hukum islam. Pertama, dlilihat dari rukunnya yaitu Al-'Aqidain (Para pihak yang berakad antara franchisor dan franchisee), Ma'qud 'Alayhi (Obyek akad yaitu hak cipta atau penggunaan merek dan produk-produk BRC ) dan Sighah al-'Aqd (pernyataan ijab dan qabul dibuktikan dengan surat perjanjian atau kontrak kerja antara franchisor dan franchisee). Kedua, pada sisi syarat obyek akad pada franchise BRC antaralain obyek Akad harus telah ada ketika akad berlangsung, obyek akad harus mal mutaqawwam (bernilai menurut syara), Bangkai, darah, miras tidak sah diperjual-belikan (produk yang digunakan tidak mengadung unsur zat yang diharamkan, dapat diserahkan ketika akad berlangsung dan yang terakhir yaitu obyek akad harus jelas dan dikenali para pihak.

Franchise fee hakekatnya adalah penggantian biaya atas development system dari franchisor. Oleh karena itu seorang franchisor bebas menetapkan seberapa besar franchise fee untuk menjual franchisenya, dilihat dari kegunaanya dan dilihat dari aspek keuangan yang dijanjikan. Serta franchise fee menggambarkan paket dukungan dan infrastruktur yang ditawarkan, maka dapat dipastikan adanya penetapan franchise fee pada Franchise BRC dibolehkan karena tidak bertentangan dengan hukum islam.

Pada franchise BRC royalty fee ditetapkan sebesar 10\% dari laba bersih franchisee, sebagai biaya promosi manajamen untuk franchisee adapun fasilitas promise yang didapatkan oleh franchisee yaitu, dipromosikan lewat radio ( seperti: MQ FM untuk diwilayah Bandung dan Dakta FM 
di Bekasi), brosur-brosur, bulletin bulanan dan terakhir iklan. Keadilan merupakan norma yang sangat diutamakan dalam islam dan diantara tanda keadilan adalah haramnya bermuamalah dengan riba karena riba tidak hanya akan menghancurkan kehidupan individu saja melainkan juga dapat menghancurkan sendi-sendi kehidupan masyarakat. Keadilan itu diaplikasikan dengan akad yang dipakai pada franchise BRC yaitu akad Musyarakah. Royalty Fee dari hasil bersih pendapatan Franchisee sesuai dengan kesepatan yang telah disepakati ketika diawal perjanjian.

\section{Pustaka Acuan}

\section{Al-Quran al-Karim}

Ahmadi, Abu. Sistem Ekonomi Islam; Prinsip-prinsip dan tujuannya. Surabaya: Bina Ilmu, 1990.

Antonio, Syafi'i .Bank Syariah: dari Teori ke Praktek. Jakarta: Gema Insani Press, 2001.

Baihaqi, Imam, Sunan Baihaki al-kubra, Kairo: Darul Hadits, 2002.

Bayu, Y. dan Maharani, Nadia. "Peringkat Doing Bussiness 2009 Indonesia Turun Kelas, Lebih Mudah Buka Usaha di Mongolia" artikel diakses pada 16 Maret 2009 dari http://www.madani-ri.com

Bukhari, Imam Syaikh al-Hufadz, Shahih Bukhari, Kairo: Maktabatul Iman, 2003.

Depag RI, Alquran dan Terjemahnya, Arab Saudi: Mujamma' al-Malik Fahd Thiba' At Al- Mush-Haf Asy-Syarif, 1415 H.

Departemen Pendidikan Nasional, Kamus Besar Bahasa Indonesia. Jakarta: Balai Pustaka, 2005.

Hakim, Lukman. Info Lengkap Waralaba. Yogyakarta: MedPress, 2008.

Hendry E. Ramdhan, Franchise Untuk Orang Awam. Jakarta: PT. Gramedia Pustaka Utama, 2009.

Hartanto Widodo "Franchise Syariah, Why Not?". artikel diakses pada 7 februari 2009 dari http://boutiquesoftware.wordpress.com.

Hikmat, Anas. "Prosedur pengajuan BRC: Prospektif dan Menguntunngkan 
Sebagai franchisee BRC " didapatkan dari Company Profile BRC, Bandung 5 Agustus 2009.

Harun, Nasrun. fiqh Muamalat. Jakarta: Gaya Media Pratama, 2007).

Ibrahim, Johannes dan Sewu, Lindawati. Hukum Bisnis; Dalam Perspektif Manusia Modern. Bandung: PT. Refika Aditama, 2004.

Nazir, M. Metode Penelitian, Cet.VI (Bogor, Ghalia Indonesia, 2005.

Nazma, Siti. Bisnis Syariah dari Nol; Langkah Jitu Menuju Kaya, Penuh Berkah dan Bermakna Jakarta: Hikmah, 2008.

Riswadi, Budi Agus. Hak Kekayaan Intelektual dan Budaya Hukum. Jakarta: PT.Raja Grafindo Persada, 2004.

Rochaety, Ety. Dkk. Metode Penelitian Bisnis: Dengan Aplikasi SPSS . Jakarta: Mitra Wacana Media, 2007.

Rumapea, Tumpal dan Haloha, Posman. Kamus Lengkap Ekonomi, eds ke-2. Jakarta: Erlangga, 1994.

Sabiq, Sayyid. fikih Sunnah, terjemahan Kamaludin A Marzuki, dkk. jilid XII, cet ke-7 Bandung: Al-Ma'arif, 1995.

Suhendi, Hendi. Fiqh Muamalah. Jakarta: PT. Raja Grafindo Persada, 2005.

Sulaiman, Imam al-hafid Abi Daud, Sunan Abu Daud, Kairo: Maktabatul Awlad Syakhu Turots, 2002.

Suseno, Darmawan Budi. Waralaba; Bisnis Minim Resiko Maksim. Yogyakarta: Pilar Humania, 2005.

Suseno, Darmawan Budi. Waralaba; Syari'ah. Yogyakarta: Cakrawala, 2008.

Syafe'I, Rachmat. fiqh Muamalat. Bandung: Pustaka Setia, 2004.

Wawancara Pribadi dengan Anas Hikmat. Bandung, 6 Oktober 2009.

Wawancara Pribadi dengan Lukman Hakim. Bandung, 6 Desember 2009.

Wijaya, Ilham M. "Menyiapkan Kaum Muda Jadi Wirauswasta" artikel diakses pada 16 Maret 2009 dari http://www.mail-archive.com

Zaid, Imam abi Abdillah Muhammad bin, Sunan Ibnu Majah, Kairo: Darul Hadits, 2002. 
, "Jumlah Pengguran di Indonesia 9.43 Juta Orang" diakses pada 05 Januari 2009 dari http://www.tempointeraktif.com

, "Pertubuhan Franchise di Indonesia", di akses pada 16 Maret 2009 dari http://www.franchisorindonesia.com

, "Profile BRC" artikel diakses pada 9 juli 2009 dari www.klik-brc

, "waralaba" diakses pada 5 Maret 2009 dari http://www.wikipedia. com

, "Fatwa MUI tentang Perlindungan Hak Kekayaan Intelektual (HaKI), diakses pada 12 september 2008 http://www.mui.or.id, 